\section{International Scientific Journal Theoretical \& Applied Science}

\author{
p-ISSN: 2308-4944 (print) e-ISSN: 2409-0085 (online) \\ Year: 2016 Issue: 11 Volume: 43 \\ Published: 02.11.2016 http://T-Science.org
}

Gulom Mirzaevich Ismailov

$\mathrm{PhD}$,

Senior Scientific Researcher of Research Institute of Uzbek Language and Literature under the Tashkent State University of Uzbek Language and Literature gulom1208@gmail.com

SECTION 29. Literature. Folklore. Translation Studies.

\title{
PHRASEOLOGICAL PICTURE OF THE WORLD IN THE TURKIC LANGUAGES
}

Abstract: The article is devoted to the study of the phenomenon of phraseological world picture and this concept of the picture of the world as one of the ways to conceptualize reality in Turkic phraseology. Besides it, in this article we systematize the achievements of different areas of research of world's pictures, description of phraseological world picture is taken. And also the universal characteristics of any world picture are also brought out.

Key words: Turkic languages, phraseological unit, phraseological world picture, national linguistic world picture.

Language: English

Citation: Ismailov GM (2016) PHRASEOLOGICAL PICTURE OF THE WORLD IN THE TURKIC LANGUAGES. ISJ Theoretical \& Applied Science, 11 (43): 5-7.

Soi: http://s-o-i.org/1.1/TAS-11-43-2 Doi: crossef http://dx.doi.org/10.15863/TAS.2016.11.43.2

\section{Introduction}

One of the most important functions of language is to fix the experience of knowing the world in the cultural and historical development of the peoples' native speakers. It is known, the language keeps culture and transmits it from generation to generation, so it plays a significant role in shaping the personality of the national character, ethnic community, the people, the nation. Most clearly illustrate features of the culture of a people nominative units, including idioms, directly correlated with the extra-linguistic reality.

Currently, in Turkology, one of the major problems of cognitive linguistics became a problem in the minds of human display a complete picture of the world. Discovering the world of man is his predstavlenieo world, that is, in his mind there is a certain "world picture".

\section{Materials and Methods}

For the first time create a speculative construction, which can be called a picture of the world, tried the Greek philosophers Anaximander, Thales, Anaximenes. More recently, similar ideas expressed by Heraclitus, Pythagoras, Philolay, Aristarchus Samos. Also a great contribution to the formation of the ancient ideas about the world have a Empedocles, Anaxagoras, Leucippus, Democritus, Epicurus, Aristotle.
Linguistic picture of the world, in our opinion, gives the most complete picture of the national mentality, as all human knowledge and achievement with a greater or lesser degree of adequacy can be transferred to the language means. Linguists said that "all linguistic plan are participate in appearance and formation the linguistic world picture. Despite of , it should be noted that there are important role of language, especially, lexica, that is lexical (phraseological) plan in reflecting and arising linguistic world picture" [4, p. 7].

It should be noted that linguistic picture of the world can be interpreted as "a body of knowledge about world, which reflected in the vocabulary, grammar, phraseology, etc." [3, p. 65] as the "idea of reality is reflected in the language of signs and their meanings - linguistic division of the world, language ordering of objects and phenomena inherent in the system of meanings of words about the world" [5, p. 68].

Concerning to above stated opinions in Linguistics have a some terms, which expressed world-outlook of people, that is "World picture", "National linguistic world picture", "Linguistic world picture", "Phraseological world picture" and etc.

National language picture of the world is not only a source Linguistic material for the confirmation 
of certain characteristics national character, but also a good source of knowledge on national mentality.

If the national language picture of the world finds its maximum expression in the lexical system, it is possible to organize it systematically: the vocabulary of the national language in this case is divided into the names of real objects of the material world and the names of conceptual artifacts of national linguistic consciousness, the second group, in turn, consists of abstract logical concepts, subjective assessment and value categories and mythical categories [2, p.287]. It is obvious that the lexeme xumo, yarimoy (Uzbek) and the phraseologism тақияда тамтавы қалмады (Kazakh, FS, 655) are heterogeneous in terms of content linguoculturological information.

A national specifics of a language picture of the world and language behavior can be explained by the specifics of people's culture, but also the structural features of the language [10, p. 44]. Most clearly the national specifics of a language picture of the world and language behavior is reflected in the phraseology of any language.

So, along with the concept of "world picture" cognitive phraseology was enough popular concept of "phraseological picture of the world".

Phraseological picture of the world - this is one of the fundamental concepts and is considered as a component of human worldview, as a set of universal and individual knowledge about the world, as the result of a creative reflection in our minds not only of the real world, but also something conceivable, we are now experiencing, although not reflecting reality. On the one hand, it is a kind of ideal, a mental formation - the amount of substantive values and perceptions of the real world, on the other hand, it indirectly derivative education, objectified phraseological values.

The modeling language picture of the world is essential phraseological image. Phraseological image fragments contributes to the structuring of a language picture of the world, related with the imaginative perception of objects surrounding the phenomena of reality, that is the implementation to date (recorded in the dictionary) value of phraseology. Phraseologisms have the ability to reflect the specific fragments of a language picture of the people of the world, speaking a particular language.

The relationship between phraseology and mental characteristics of the people can be seen in two ways: moving away from mental traits find their reflection in phraseologisms, and vice versa through the analysis of phraseology identify mental traits that are typical of the people - a native speaker. For example:

тупканинг тагида (Uzbek, O'TIL, IV, 192) түйенің тұявы түсетін жер (Kazakh, FS, 703) - ийт өлген жер (Karakalpak, QTF, 53), these phraseologisms have a concept "far". Its shown from these phraseologisms, that one of the occurrence is expressed with various concepts depending on every ethnos Uzbek, Kazakh and Karakalpak.

Phraseological picture of the world is most clearly and accurately reflects the spirit of the people, its national mentality, as well as the cultural and historical experience of knowing the world, due to its expressiveness and emotionality. Objects reality different nations comprehended and semanticized differently; the fragment phraseological picture of the world that is characteristic of the people, can completely be ignored in phraseological picture of the world or other people considered other means of linguistic expression. Thus, phraseological picture of the world - is specific to each language.

Thus, phraseological picture of the world is a fragment of linguistic world picture. Phraseological language foundation - a valuable source of information about the culture and mentality of the people, it would be conserved as a representation of the people of the world around him. "Phraseological picture of the world - is a universal, common to all languages, the imaging system of special language units, the transmission characteristics of the national world picture" [9]. Phraseological picture of the world reveals the universal human and national peculiar properties of phraseological system in different languages. The problem of the universal and national in phraseology are devoted many Turkologists and other linguists.

\section{Conclusion}

The most important way of human orientation in the objective world is its linguistic consciousness, receiving expression in the language picture of the world's people. In its structure and content are fixed for the current language realities and concepts of world, shaped receiving symbolization. This symbolization permeates all kinds of creativity (history, culture, folklore, literature and etc.) and language, including its phraseological fund of every language. Name of key concepts of culture is often part of the phraseological fund as the components in symbolic recognition of which is based semantic space phraseological picture of the world in any language.

In phraseological pictures of the world of each of the national language are reflected particular lifestyle, customs and traditions, history and culture of a people, the geographic and climatic conditions of his stay, value-norm system. Therefore, for any people characterized by phraseological pictures of the world as a universal, and distinctive national features. 


\begin{tabular}{l|lrl|l|ll} 
& ISRA (India) & $=\mathbf{1 . 3 4 4}$ & SIS (USA) & $=\mathbf{0 . 9 1 2}$ & ICV (Poland) & $=\mathbf{6 . 6 3 0}$ \\
Impact Factor: & ISI (Dubai, UAE) $=\mathbf{0 . 8 2 9}$ & PUHIL (Russia) $=\mathbf{0 . 2 3 4}$ & PIF (India) & $=\mathbf{1 . 9 4 0}$ \\
& GIF (Australia) & $\mathbf{0 . 5 6 4}$ & ESJI (KZ) & $=\mathbf{1 . 0 4 2}$ & IBI (India) & $\mathbf{= 4 . 2 6 0}$ \\
& JIF & $\mathbf{1 . 5 0 0}$ & SJIF (Morocco) & $=\mathbf{2 . 0 3 1}$ & & \\
\hline
\end{tabular}

\section{References:}

1. Aytbay O, Usenbaev G (2012) Қаzақ frazeologizmderi men perifrazdary. - Almaty, 2012.

2. Kornilov OA (2011) Yazykovye kartiny mira kak proizvodnye natsional'nykh mentalitetov. — Moscow: Izdatel'stvo «KDU», 2011.

3. Maslova VA (2001) Lingvokul'turologiya. Moscow: Akademiya, - 2001.

4. Maxmudov N (2015) Olamning lisoniy manzarasi va syz yzlashtirish // Yzbek tili va adabieti. - №3. - Toshkent, 2015. - pp. 3-12.

5. Popova ZD, Sternin IA (2006) Semantikokognitivnyy analiz yazyka. - Voronezh: Istoki, 2006.

6. Sagidolda S (2011) Tyrki-mongol tildik baylanysy: toponimiya and frazeologiya. Astana, 2011.
7. Teliya VN (1996) Russkaya frazeologiya. Semanticheskiy, pragmaticheskiy lingvokul'turologicheskiy aspekty. - Moscow: Shkola «Yazyki russkoy kul'tury», 1996.

8. Turdieva DA (2010) Gendernye otnosheniya vo frazeologicheskikh sistemakh frantsuzskogo i uygurskogo yazykov: avtoref.kand.filol.nauk. Almaty, 2010.

9. Khayrullina RK (1999) Sopostavitel'naya frazeologiya russkogo i bashkirskogo yazykov. Ufa, 1999.

10. Khayrullina RK (2008) Frazeologicheskaya kartina mira: ot mirovideniya $\mathrm{k}$ miroponimaniyu. - Ua: Izd-vo BGPU, 2008. 